\title{
Autocracia burguesa e a práxis revolucionária de Florestan Fernandes
}

\author{
Keila Carvalho ${ }^{1}$ \\ https://orcid.org/0000-0003-0391-1179 \\ ${ }^{1}$ Centro Federal de Educação Tecnológica Celso Suckow da Fonseca, Departamento de Ensino Médio Técnico, \\ Coordenadoria de Sociologia, Rio de Janeiro, RJ, Brasil
}

\begin{abstract}
Autocracia burguesa e a práxis revolucionária de Florestan Fernandes
Resumo: Em um cenário atual de escalada do autoritarismo no contexto político, nacional e internacional, as lições teóricas e políticas legadas por Florestan Fernandes são ferramentas importantes para ajudar a iluminar novas e antigas estratégias no enfrentamento desses desafios contemporâneos. Após sua consagração acadêmica e em meio à aposentadoria compulsória decorrente do Ato Institucional $n^{\circ} 5$ em plena ditadura civil-militar brasileira, Florestan identificou nos processos políticos de seu tempo a necessidade de construção de nova uma práxis. Desse modo, o objetivo deste artigo é resgatar os sentidos dessa práxis em meio às consequências pessoais e dramáticas da intensificação da autocracia burguesa, a distensão da ditadura e a transição democrática, passando pelos novos constrangimentos da chamada Nova República até 1995, quando de seu falecimento. Para tanto, foi utilizada pesquisa bibliográfica e documental, compreendendo tanto os registros teóricometodológicos desse período tardio da trajetória de Florestan quanto as experiências de engajamento político e os conteúdos de sua intervenção militante.
\end{abstract}

Palavras-chave: Florestan Fernandes. Práxis. Autocracia Burguesa. Ditadura Civil-Militar. Nova República.

\section{Bourgeois autocracy and the revolutionary praxis of Florestan Fernandes}

Abstract: In a current scenario of escalating authoritarianism in the political context, national and international, the theoretical and political lessons left by Florestan Fernandes are important tools to help to illuminate new and old strategies facing these contemporary challenges. After his academic consecration and in the midst of the compulsory retirement resulting from Institutional Act $\mathrm{n}^{\circ} 5$ in the middle of Brazilian civil-military dictatorship, Florestan identified in the political processes of his time the need of building a new praxis. Thus, the objective of this article is to rescue the senses of this praxis amid personal and dramatic consequences of the intensification of the bourgeois autocracy, the distension of the dictatorship and the democratic transition, going through the new constraints of the so-called New Republic until 1995, when he died. To this end, was used bibliographical and documentary research that comprised both the theoretical and methodological records of this late period in Florestan's trajectory as well as the experiences of political engagement and the contents of his militant intervention. Keywords: Florestan Fernandes. Praxis. Bourgeois Autocracy. Civil-Military Dictatorship. New Republic.

Recebido em 23.06.2020. Aprovado em 01.09.2020. Revisado em 24.09.2020.

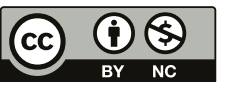

Este é um artigo publicado em acesso aberto (Open Access) sob a licença Creative Commons Attribution NonCommercial, que permite uso, distribuição e reprodução em qualquer meio, sem restrições desde que sem fins comerciais e que o trabalho original seja corretamente citado. 


\section{Introdução}

O objetivo deste artigo consiste em recuperar o legado de Florestan Fernandes (1920-1995) construído em uma fase tardia de sua trajetória, a partir da aposentadoria compulsória decorrente do Ato Institucional n. 5 em plena ditadura civil-militar brasileira ${ }^{1}$, nos últimos momentos de sua vida. O que busco apontar é que Florestan construiu, nesse período, uma práxis revolucionária que vai encontrar ressonância tanto nas suas contribuições teórico-metodológicas quanto nas suas experiências políticas e públicas de engajamento. Além disso, pretendo resgatar as lições dessa práxis, no cenário contemporâneo de escalada do autoritarismo no contexto político, nacional e internacional no lastro da crise atual do capital, parte da necessidade de construção de ferramentas que contribuam para iluminar novas e antigas táticas e estratégias no enfrentamento dos desafios dos nossos tempos.

Não tenho a pretensão de analisar a totalidade do pensamento sociológico de Florestan, menos ainda de esgotar a experiência biográfica desse sociólogo². Por isso mesmo, o foco aqui será a fase mais tardia (1969-1995), que compreendeu sua construção de uma práxis revolucionária. Foi utilizada a pesquisa empírico-documental, que constituiu diferentes modalidades de registros acadêmicos e de intervenções construídas na arena pública e política durante o período 1969-1995: artigos jornalísticos e entrevistas, participações em movimentos sociais e organizações político-partidárias, entre outros. Embora esses registros não digam respeito à totalidade da trajetória de Florestan, eles podem dizer muito sobre a práxis que Florestan construiu no referido período.

O artigo está estruturado em duas partes. A primeira (1969-1984) aborda os eventos políticos e biográficos durante o período da ditadura civil-militar, principalmente com a institucionalização do AI-5. Após sua cassação, Florestan aderiu abertamente ao marxismo e à defesa e autoconstrução de uma práxis revolucionária. A segunda parte (1984-1995) compreende a transição para a Nova República, marcada pela atuação de Florestan como publicista e como deputado federal pelo Partido dos Trabalhadores (PT-SP).

Este artigo busca demonstrar que, no referido período, as tendências mais gerais de suas formulações teóricas e metodológicas refletem e são, também, refletidas em seu engajamento político. No sentido de uma crítica imanente, busco compreender os conceitos e as categorias do autor em uma apreensão desses instrumentos a partir de seus variados objetos empíricos. Por outro lado, no sentido de uma crítica que transcende Florestan, o objetivo é realizar uma interpretação especialmente localizada em suas experiências de engajamento político, a fim de contribuir para o enfrentamento aos desafios contemporâneos.

\section{Sob o peso da autocracia burguesa (1969-1984)}

Foi com e contra o pano de fundo da ditadura civil-militar brasileira (1964-1985) que Florestan construiu sua práxis revolucionária. Em setembro de 1964, em virtude de um inquérito policial-militar instaurado na Universidade de São Paulo (USP), Florestan foi convocado para depor e permaneceu preso por alguns dias. Prevendo o curso dos acontecimentos, Florestan já havia redigido a carta intitulada Autodefesa com antecedência. A carta foi endereçada ao coronel responsável pelo inquérito e posteriormente divulgada na grande imprensa. Sobre esse inquérito, Florestan (1991, p. 11, grifo nosso) observou que:

Em 1964, a minha inclusão em uma lista de professores a serem inquiridos pelos policiais militares estava ligada à minha própria vida intelectual. Quando eu cheguei à universidade, eu era o Florestan de origem proletária, o que nunca neguei. Eu não procurei na universidade um meio de ascender socialmente e me confundir com as elites. Sempre tive um papel ativo: me tornei assistente na Faculdade de Filosofia, e a primeira coisa que comecei a fazer foi combater a cátedra, uma forma arcaica de autoridade do professor, e a lutar para a autogestão coletiva do departamento. Inclusive, defendi a gestão paritária. Fiz parte das campanhas de defesa da escola pública, pelas reformas estruturais de base e pela reforma universitária. Em 1964, puniu-se esse padrão intelectual, indesejável em uma sociedade na qual as elites querem manter a sua ordem de qualquer maneira.

Em decorrência desse processo, Florestan se afastou do país e ocupou o cargo de professor visitante na Universidade de Columbia, nos Estados Unidos, entre 1965 e 1966. Refletindo sobre seus primeiros pronunciamentos acerca da conjuntura política brasileira do período, Florestan (1968, p. 10-11) considera que: 
como antigo aluno e professor da escola, vi-me na contingência de expressar-me com certa ressalva, desagradando assim os que gostariam de calar-me sem, contudo, satisfazer aos que esperavam uma acusação veemente e intempestiva ao regime ditatorial. [...] Ao reiniciar minhas atividades docentes, de volta ao Brasil (em fins de janeiro de 1966), deparei com condições bem piores do que as que poderia imaginar e dei-me conta da terrível marginalidade a que fora relegada a juventude universitária.

Retornando da Universidade de Columbia à USP, Florestan participou ativamente do movimento universitário contra a ditadura em curso. Entretanto, por força do AI-5, teve decretada sua aposentaria compulsória em 1969, permanecendo, novamente, fora do país até $1972 .{ }^{3}$ Durante o exílio, foi professor na Universidade de Toronto, momento em que aderiu abertamente ao marxismo ${ }^{4}$. Segundo Helóísa Fernandes (2011a, p. 17):

Seu exílio se transforma num período de vida dramático, que prepara a eclosão do novo. Dois textos dão testemunho da ruptura. O primeiro, de 1969, Sociólogos: os novos mandarins?, escrito quando chegou no Canadá, no qual afirma "eu sou, ao mesmo tempo, sociólogo e socialista” [...]. O outro, A geração perdida, escrito quando retornou ao Brasil, mas imerso na experiência do exílio. Texto duro, pesado, doloroso. Implacável, Florestan quer saber onde nós, socialistas, falhamos, e para onde vamos. No centro do seu discurso, já não está a sociologia, mas o povo.

Desenraizado do espaço institucional da universidade, a construção de uma práxis revolucionária foi, também, a resposta de Florestan à crise pessoal dramática pela qual passou: "Depois de 1969, a minha identificação com a sociologia e com os papéis intelectuais do sociólogo sofreu uma crise. A crise surgiu entre 1969 e 1972, em Toronto [...]. Para ficarmos no essencial: a sociologia perdeu o seu encanto, para mim" (FERNANDES, 1980, p. 13). Embora os eventos pessoais traumáticos não possam ser entendidos como determinantes desse processo, esses elementos não podem ser meramente descartados.

Ao retornar ao país em fins de 1972, Florestan (2011, p. 99) concluiu a redação final de A revolução burguesa no Brasil, obra que, segundo o mesmo, consistiu em uma "tentativa de denúncia intelectual e de luta política", onde afirma a impossibilidade histórica de uma revolução no interior da ordem burguesa:

O golpe de Estado de 1964 obrigou-me a procurar uma explicação sociológica que suplantasse a visão tradicional e conciliadora da formação e desenvolvimento da sociedade brasileira, forjada e mantida pelas elites intelectuais das classes dominantes (no passado e no presente). [...] Não se tratava, apenas, de defender a "liberdade" e a "democracia". Porém, de pôr em evidência que a sociedade de classes engendrada pelo capitalismo na periferia é incompatível com a universalidade dos direitos humanos: ela desemboca em uma democracia restrita e em um Estado autocrático burguês, pelos quais a transformação capitalista se completa apenas em benefício de uma reduzida minoria privilegiada e dos interesses estrangeiros com os quais se articula institucionalmente. (FERNANDES, 2011, p. 116-118, grifo do autor).

Sob os impactos do golpe de 1964, Florestan (1977, p. 201) se propôs a analisar a "revolução burguesa" sob a chave do capitalismo dependente, partindo de "categorias históricas do capitalismo, da sociedade de classes e do Estado democrático a uma adequação mais rigorosa às condições brasileiras". As análises sobre as relações de classe e o lugar do Brasil na geopolítica do capitalismo mundial passam a ser o centro de suas contribuições teórico-metodológicas, nesse momento mais tardio de sua trajetória. $\mathrm{O}$ entendimento de que o golpe de 1964 representa uma contrarrevolução preventiva aprofundou sua análise sobre a gênese autocrática do Estado brasileiro:

O golpe de Estado de 1964 abriu a rota para o "desenvolvimento econômico acelerado". O setor militar tomou como meta a estabilidade política a qualquer preço, oferecendo ao grande capital estrangeiro e nacional uma oportunidade histórica única, de exploração intensiva de mão de obra barata, de apropriação devastadora de recursos naturais pilhados de forma colonial, de financiamento público ou sob a responsabilidade do Estado de uma vasta infraestrutura à implantação do modo de produção capitalista monopolista (ou oligopolista) (FERNANDES, 2010, p. 268).

No caso brasileiro, a revolução burguesa conjugou a dimensão autocrática da dominação, através do particularismo e do conservadorismo sociocultural e político entranhado nas elites burguesas, com a conformação de uma economia capitalista satélite. Por isso mesmo, o capitalismo dependente e subdesenvolvido é um 
capitalismo selvagem e difícil, cuja viabilidade se decide, com frequência, por meios políticos e no terreno político (FERNANDES, 2005).

Ou seja, seu caráter selvagem se deve à combinação entre expropriação e autocracia. O que sugere, portanto, que a revolução burguesa na periferia é, por excelência, um fenômeno essencialmente político, realizado por meio do Estado, através da criação, consolidação e preservação de estruturas de poder predominantemente políticas, submetidas ao controle da burguesia ou por ela controláveis em quaisquer circunstâncias (FERNANDES, 2005). A autocracia burguesa é decorrência, portanto, da própria estrutura compósita da sua burguesia brasileira (CARDOSO, 1995), cujos objetivos se limitam a manter ordem, salvar e fortalecer o capitalismo, e impedir que a dominação e o controle burguês sobre o Estado nacional se deteriorem (FERNANDES, 2005).

É por meio do reacionarismo e autoritarismo - tendência intrínseca à crise da sociedade burguesa na era do capitalismo monopolista (FERNANDES, 1979) - que se revela a essência autocrática da dominação burguesa no Brasil e sua propensão a produzir formas abertas e sistemáticas de ditadura de classe (FERNANDES, 2005). A ditadura consiste, portanto, na manifestação do poder burguês em sua manifestação mais brutal e reveladora - a ditadura de classe preventiva ou contrarrevolução preventiva. Ou seja, um subproduto essencial da revolução burguesa no Brasil (1979). Não se trata "apenas [de] uma imagem invertida do Estado democráticoburguês, porém à forma necessária que o Estado precisa assumir como instrumento de dominação externa e do despotismo burguês reacionário", próprio das nossas elites (FERNANDES, 1979, p. 39).

É pela via estatal, portanto, que a dominação burguesa no País apresenta seus padrões autocráticos. A ditadura civil-militar, especialmente com seu endurecimento via AI-5, revelou, segundo Florestan, ser um paraíso burguês: representou a criação de condições normais para o funcionamento e crescimento da sociedade burguesa, afetada anteriormente tanto pela crise do capital quanto pela eclosão do socialismo na periferia (FERNANDES, 2005, p. 421). Essas seriam, então, as manifestações da contrarrevolução preventiva no Brasil:

fruto de um movimento burguês contrarrevolucionário, a autodefesa da burguesia associou-se ao recurso à guerra civil, que não se concretizou por falta de resposta e, ainda, porque o golpe de Estado revelou-se uma técnica suficiente de transição política. O enrijecimento da ordem evoluiu naturalmente, assim, para uma excessiva e desnecessária "demonstração de força" preventiva. O que vinculou a militarização de funções repressivas do Estado e a preservação da segurança nacional com a criação de um novo status quo, necessário à instauração e à persistência da ditadura de classes aberta e rígida. A curto prazo, cabia ao Estado nacional "deprimir e comprimir" o espaço político e jurídico de todas as classes ou estratos de classe (mesmo burgueses e pró-burgueses) que se erguessem ostensivamente contra a transição, opondo-se a ela por meios violentos. (FERNANDES, 2005, p. 399).

O pacto contrarrevolucionário de 64 representou, segundo Florestan Fernandes (2005) "um padrão compósito e articulado de dominação burguesa" mediante a crise dessa dominação no período 1961-64, momento em que as classes passaram a realizar requisições democráticas, nacionais e populares. Não à toa, "o alargamento e o aprofundamento desta contradição, precipitados pelas lutas e tensões sociais no período, erodiam consistentemente o lastro hegemônico da dominação burguesa." (PAULO NETTO, 2007, p. 42).

Restava a Florestan, portanto, repensar o horizonte político e demarcar novas tarefas na construção de sua práxis: debruçando-se sobre a necessidade e a possibilidade de uma revolução nos quadros de um capitalismo periférico e dependente, e a consequente impossibilidade de compatibilizar capitalismo e democracia (FERNANDES, 2005). Dadas as novas tarefas intelectuais e os desafios políticos, Florestan levou até as últimas consequências a unidade entre o militante e o sociólogo, sob a forma de uma práxis revolucionária.

O parâmetro da práxis de Florestan é a própria realidade em processo, mantendo as explicações no nível das atividades práticas e das aspirações dos grupos e classes sociais empenhados na revolução (FERNANDES, 1980). Ou seja, a fim de evitar um radicalismo intelectualista que beira a fabulação, o intelectual precisa acompanhar, no plano teórico, os delineamentos tomados no terreno da prática pelas classes sociais. Essa reorientação foi devedora tanto dos processos sociais em curso quanto das investigações teóricas que desenvolvera. No terreno da práxis, sabemos que esses dois elementos se coadunam e que apenas analiticamente podemos distingui-los.

A passagem dos anos 1970 para 1980 foi marcada por certa flexibilização da ditadura. Florestan, o militante solitário (CANDIDO, 1987), deu início a uma intensa atividade jornalística por meio dos chamados compactos críticos $^{5}$, durante e após o período de revogação da censura prévia pelo regime. A partir de 1974, com o governo Geisel (1974-1979), a estratégia da distensão foi mais um reflexo do desgaste do regime do que 
propriamente a vitória de um apelo democrático. Entre as medidas de distensão da ditadura, podemos citar a revogação do AI-5 em 1978 e a suspensão parcial da censura prévia aos meios de comunicação. Foi também nesse período que o chamado milagre econômico mostrou seus primeiros sinais de esgotamento, associado à crise do capital que recomeçava a repercutir nos países do capitalismo periférico. $\mathrm{O}$ aumento no custo de vida e a contenção dos salários aumentaram o descontentamento dos trabalhadores. Em 1978, os metalúrgicos da região do ABC Paulista protagonizaram o maior ciclo grevista da história do País.

Estando o regime civil-militar ainda mais desgastado, o governo Figueiredo (1979-1985) deu seguimento ao processo de distensão política. Em 1978, foi promulgada a problemática Lei da Anistia, que não admitiu nenhuma punição aos responsáveis pela repressão institucional e, na mesma época, houve o fim do bipartidarismo. As greves no ABC Paulista se mantiveram pelos anos de 1979 e 1980, marcando um novo momento do movimento sindical brasileiro e a necessidade de uma nova organização nacional do movimento de trabalhadores. Florestan via com entusiasmo a construção desses movimentos, alguns deles inéditos em amplitude e em profundidade, embora apontasse a necessidade de articulação desses movimentos com organizações e partidos identificados com o socialismo revolucionário (FERNANDES, 1982).

Segundo Florestan, o desgaste político da ditadura representou uma "era de prestação de contas", embora não representasse o desgaste da autocracia burguesa (FERNANDES, 1982, p. 7). Ou seja, o que estava em jogo não era a crise da autocracia burguesa, mas a crise da contrarrevolução preventiva. Não à toa, considerou que "não foram as forças organizadas da sociedade brasileira que desgastaram a contrarrevolução e conduziram o governo ditatorial às atuais perplexidades" (FERNANDES, 1982, p. 8). A Nova República permanece como uma variante histórica, portanto, do Estado autocrático burguês.

\section{Desafios da Nova República, ou democracia de cooptação (1984-1995)}

Nesse momento, Florestan se dedicou a uma luta com fronteiras maiores, utilizando seu conhecimento e notoriedade para atingir públicos ainda mais amplos. No bojo de sua práxis, foi significativa sua atividade jornalística, principalmente no jornal Folha de São Paulo a partir de 1984, quando foi convidado para colaborar na seção Tendências/Debates. ${ }^{6}$ Esse é um marco importante para delimitar a intensa atuação como publicista ${ }^{7}$ de Florestan Fernandes. No início da década de 1980, a Folha de São Paulo se tornou uma das forças ativas do movimento Diretas Já, em um momento no qual grande parte da imprensa ainda não estava convencida desse caminho. Foi nesse contexto que o Jornal abriu espaço, em seu corpo editorial, para escritores dos mais variados matizes políticos.

O surpreendente conjunto de aproximadamente quinhentos artigos que Florestan publicou na Folha trazia reflexões que se inserem diretamente na conjuntura política da redemocratização e que conformam também um modo determinado de intervenção política. Subjazia, por parte de Florestan, o entendimento de que os jornais poderiam servir como uma tribuna de divulgação sobre o tipo de república que o País precisava construir. Visualizando tamanha potencialidade, sua dedicação e seu compromisso foram marcantes em sua relação com a coluna da Folha ${ }^{8}$. Além disso, constam publicações de Florestan no Jornal do Brasil, em que também foi colaborador regular, e em outros periódicos, como Pasquim, Portugal Democrático, Jornal de Brasília, Decisão, Jornal do Socialista, CPB Notícias, Folha de Londrina, Jornal Leia e o argentino La Opinión.

No fundo, cada artigo surgia como se eu estivesse escrevendo cartas aos leitores, largando a pele de sociólogo em troca do papel de publicista, agarrado com tenacidade às causas das classes oprimidas, à ótica socialista da luta de classes e à difusão da desobediência civil com o patamar inicial de uma revolução democrática de cunho proletário e popular. Solitário e impotente para ir mais longe, dediquei-me a uma espécie de jornalismo político que partia da conjuntura para os movimentos mais fundos da transformação da sociedade, combinando o saber sociológico acumulado ao longo dos anos à necessidade de servir à imensa maioria dos espoliados e àqueles que, como eu, estão dispostos a tudo para que o Brasil supere para sempre uma degradante tradição de embrutecimento e de exclusão dos oprimidos. (FERNANDES, 1986, p. 11, grifo nosso). 
Nesse contexto e depois de um hiato de quase trinta e cinco anos longe de organizações partidárias, Florestan se filiou ao Partido dos Trabalhadores (PT), por meio do qual exerceu a atividade parlamentar como deputado federal constituinte em 1987, tendo sido reeleito em 19919. No lançamento da candidatura como deputado constituinte, Florestan colocou para si duas tarefas: "servir como militante da campanha pela Constituinte" e, sendo eleito, batalhar por uma Carta Constitucional "que se torne instrumento de luta política dos oprimidos e das classes trabalhadoras" (FERNANDES, 2006, p. 123). Essas tarefas partiam, nesse momento, da avaliação do sociólogo de que a nova Constituição é um objeto de disputa tanto do reacionarismo quanto de uma democracia popular que deveria apontar para uma construção socialista. No manifesto Compromisso político, publicado no panfleto de lançamento da campanha, Florestan Fernandes (2006, p. 138-139) afirma:

\begin{abstract}
Não sou operário nem pretendo qualificar-me como equivalente do operário na condição de "trabalhador intelectual" e de "professor". Sou um ativista marxista e me apresento como candidato a deputado federal pelo PT, ou seja, como intelectual a serviço deste partido. [...] Não pretendo tornar-me um "político profissional", iniciar uma "carreira política". [...] Almejo desdobrar as minhas atividades em duas direções. Primeiro, na campanha política, aproveitar todas as oportunidades para que os debates aumentem a consciência de classe dos trabalhadores [...]. Segundo, se for eleito, disponho-me a dedicar-me, nos limites de minhas faculdades intelectuais e políticas, ao papel efetivo de um mandatário dos interesses reais do proletariado como classe e de suas organizações sindicais, partidárias e culturais.
\end{abstract}

$\mathrm{Na}$ Assembleia Nacional Constituinte (ANC), Florestan apresentou 93 emendas, tendo sido aprovadas 34. A dedicação ao mandato fez de Florestan um dos deputados mais conhecidos da ANC, fato este que não deixa de estar relacionado à sua atividade jornalística, que exerceu de forma paralela. Posteriormente à promulgação da nova Constituição, Florestan participou ativamente do processo de elaboração, discussão e aprovação da Lei de Diretrizes e Bases da Educação Nacional, iniciado em dezembro de 1988.

Foi por meio de seus artigos jornalísticos que Florestan desenvolveu suas críticas mais severas ao reacionarismo burguês da ditadura civil-militar e das forças sociais de sua sustentação, denunciando também a falácia do desengajamento dos militares no processo de democratização e as transações políticas que representavam uma falsa promessa de transformação social com a Nova República. Segundo Florestan Fernandes (1986), esses aspectos revelariam a comprovação empírica de sua descrença na possibilidade de realização da democracia burguesa. Para Florestan (1986), não seria sob a ditadura, mas sob a Nova República que teríamos a mais clara definição política das impossibilidades dessa democracia no Brasil.

Segundo Florestan (1989), a Nova República está imersa em contradições que se relacionam ao próprio caráter da obsolescência da ditadura civil-militar em sua transição para uma democracia de cooptação. Esse processo de transição ocorreu por uma divisão no interior da burguesia quanto às soluções que deveriam ser implementadas para superar os "dilemas postos pelo funcionamento da sociedade civil e pela organização do Estado" (FERNANDES, 1989, p. 54). O que está em jogo, portanto, é a manutenção da dominação burguesa.

Na iminência de crise do poder burguês, a Nova República seria a forma de transição (a chamada transição transada) entre os setores civis e militares para readequar a Constituinte ao padrão de desenvolvimento do capitalismo monopolista. O que poderia ser uma oportunidade para desenvolver uma revolução dentro da ordem se revelou, no decurso desse processo, a perpetuação do Estado de caráter autocrático, ainda que por trás da máscara da República democrático-representativa. Nesse sentido, a transição democrática foi uma operação de conciliação pelo alto, a interrupção da contrarrevolução preventiva de 1964 com vistas a barrar, mais uma vez, as potencialidades das lutas sociais em curso. A "Nova República", prolongamento da autocracia burguesa por outros meios - agora, com a chamada "democracia de cooptação" -, demonstra a "resistência sociopática" das classes dominantes à mudança social e suas manobras dissimuladoras em torno da "questão democrática" (FERNANDES, 1990, p. 5-8).

Florestan foi reeleito em 1990, permanecendo até o final de seu mandato, em $1994^{10}$. Durante todo o período em que esteve no PT, participou organicamente das atividades partidárias. Desde o início, Florestan não se incorporou acriticamente ao PT. Ao longo do segundo mandato, intensificou suas críticas aos rumos do partido que, de acordo suas palavras, avançou em direção a modelos burgueses em detrimento de "modelos 
propriamente proletários e socialistas", por enfatizar o que chamou de "técnica eleitoral competitiva" (FERNANDES, 1991, p. 17):

No momento em que o PT renegar a sua função de servir de espinha dorsal à luta política dos trabalhadores, deixando de ser um partido de revolução contra a ordem, ele deixará de ter importância para a instauração da democracia com igualdade social no Brasil. [...] o processo eleitoral não é o objetivo em si, é um processo político no qual está em jogo a conscientização do estudante, do trabalhador, a identidade socialista. O objetivo é desempenhar tarefas políticas do partido. É lamentável dizer que isto não ocorreu. (FERNANDES, 1991, p. 16-17).

Em sua emblemática participação no programa Roda Viva (FERNANDES, 1994) da TV Cultura, Florestan foi questionado sobre o PT e as políticas de conciliação de classe já em curso. Nesse momento, respondeu que estão diante dele duas possibilidades, dependendo dos rumos do partido: permanecer no PT e tentar acompanhar a marcha do partido ou, "se essa marcha se revelar deficiente ou indesejável", romper com o PT e retornar à sua condição de militante solitário (FERNANDES, 1994) - condição esta que o acompanhou em grande parte de sua trajetória ${ }^{11}$.

$\mathrm{Na}$ construção e vivência de sua práxis revolucionária, Florestan se vinculou de forma profunda a movimentos e a organizações que, em seu tempo, realizaram a luta política dos de baixo. A partir de uma "relação democrática entre o intelectual e o público" (FERNANDES, 1978, p. 66-67), considerava que o sociólogo deveria estar disposto a enfrentar novos papéis intelectuais, dependentes de "novos laços orgânicos - com a fábrica, com o campo, com os sindicatos, os partidos operários etc." (FERNANDES, 2011, p. 90). Ou seja, o intelectual precisava colocar-se a serviço do povo, e não apenas lutar por ele (FERNANDES, 1977, p. 246). Nas próprias palavras de Florestan Fernandes (2011, p. 90), esse processo deve passar por uma reeducação do intelectual "para tornar-se, ele próprio, uma força social revolucionária".

Essa práxis construída por Florestan esteve inspirada na figura do intelectual como tribuno do povo, no sentido reivindicado por Lênin (1978) - uma das maiores referências intelectuais e políticas ao final de sua trajetória, quando aderiu de forma aberta ao marxismo. De acordo com José Paulo Netto (1987), a recuperação da categoria de revolução (fora da ordem) foi significativa para a construção da práxis de Florestan, que teve a pedagogia socialista como o centro de sua atividade política e teórica. Segundo Paulo Netto (1987, p. 304, grifo nosso):

O pedagogo socialista não abre mão da condição intelectual (teórica) - esta é ainda mais exigida pela prova da educação política coletiva; mas se redefine enquanto só se realiza na medida em que o pedagogo é também receptor (e coesionador) da experiência do coletivo a que se reporta. A pedagogia socialista não funda a consciência revolucionária (desejá-lo seria pretender a substituição da vanguarda, do partido); contudo, desenvolve-a, atualiza-a, potencia-a no seu processamento (e, pois, é parte integrante da ação da vanguarda). Rigorosamente, a evolução de Florestan, pelas vias que tentei esboçar sumariamente, culmina no ponto em que ele investe na pedagogia socialista e se põe como tribuno do povo, revolucionário [...] segundo o ideal lenineano.

\section{Considerações finais}

Estudos sobre as condições intelectuais costumam demonstrar que momentos de crise das formas e relações sociais, muitas vezes relacionados a derrotas políticas e culturais, são propícios ao questionamento do intelectual sobre o mundo e ao autoquestionamento do intelectual sobre sua própria condição. Florestan realizou, especialmente em uma fase tardia, seus questionamentos e autoquestionamentos da condição intelectual também a partir de um momento crítico de sua existência social, que se tornou parte constitutiva de sua trajetória individual e que se coaduna com a história recente do País.

A ruptura institucional com a USP, que reverberou em uma crise psicológica, representou um afastamento da figura do sociólogo profissional em direção a um envolvimento mais estreito com o povo: Florestan se esforçou para realizar uma unidade possível entre sociologia e revolução ou, em outros termos, entre conhecimento do mundo e sua transformação. Talvez resida aí o elemento fundamental que ajuda a amparar sua práxis: no escopo 
de sua teoria sociológica, Florestan considerou o papel positivo de criação política à luz de suas contribuições teórico-metodológicas. O horizonte político socialista passa a ser entendido como alternativa histórica, ou seja, não deve ser meramente descartado se não for realizado no curto ou no médio prazo.

Ao mesmo tempo, as posições e perspectivas de classe que Florestan adota não devem ser entendidas como o produto de uma evolução biográfica, mas, sim, como processos dessa trajetória. Essas perspectivas e posições foram materializadas na sua práxis, que se torna especialmente visível a partir de um contexto profundo de crise social - compreendendo tal contexto da ditadura como mecanismo detonador dessa atividade. Esse é o panorama que descortinou a práxis militante de Florestan em seus diferentes matizes.

O avanço do conservadorismo e autoritarismo que se acirram na conjuntura brasileira, recolocam a necessidade premente de definição de táticas e estratégicas para esse enfrentamento e a recomposição contrahegemônica da luta de classes. Para contrapor a esse repertório autocrático, o legado de Florestan apresenta uma impressionante vitalidade teórica e prática. O ciclo da Nova República, com suas promessas democráticas, chega ao seu esgotamento. Isso nos coloca desafios que não podem ser anacrônicos - sobretudo em relação à possibilidade por vias dentro da ordem. É nesse sentido que a práxis de Florestan Fernandes segue com uma atualidade imprescindível ao tempo presente.

\section{Referências}

CANDIDO, A. Amizade com Florestan. In: D’ INCAO, M. A. (org.). O saber militante: ensaios sobre Florestan Fernandes. São Paulo: Unesp, 1987.

CARDOSO, M. L. Capitalismo Dependente, Autocracia Burguesa e Revolução Social em Florestan Fernandes. Instituto de Estudos Avançados da Universidade de São Paulo, São Paulo, 1995. Disponível em: http://www.iea.usp.br/publicacoes/textos/ limoeirocardosoflorestan1.pdf. Acesso em 11 maio 2020.

D'ARAUJO, M. C. O AI-5. Fatos e imagens: artigos ilustrados de fatos e conjunturas do Brasil, [201-?]. Disponível em: http://cpdoc. fgv.br/producao/dossies/FatosImagens/AI5. Acesso em: 7 maio 2020.

FERNANDES, F. Apontamentos sobre a "teoria do autoritarismo". São Paulo: Hucitec, 1979.

FERNANDES, F. Brasil: em compasso de espera: pequenos escritos políticos. Rio de Janeiro: Ed. da UFRJ, 2011.

FERNANDES, F. Carta a Barbara Freitag de $1^{\circ}$ dez. 1970. In: FREITAG, B. Florestan Fernandes por ele mesmo. Estudos Avançados, São Paulo, v. 10, n. 26, jan./abr. 1996.

FERNANDES, F. A condição de sociólogo. São Paulo: Hucitec, 1978.

FERNANDES, F. A Constituição inacabada. São Paulo: Estação Liberdade, 1989.

FERNANDES, F. A ditadura em questão. São Paulo: T. A. Queiroz, 1982.

FERNANDES, F. Entrevista concedida a Heródoto Barbeiro. Roda Viva, TV Cultura, 1994.

FERNANDES, F. Entrevista concedida a Paulo de Tarso Venceslau. Teoria e Debate, São Paulo, n. 13, 1991. Disponível em: https:// teoriaedebate.org.br/1991/01/20/florestan-fernandes/. Acesso em: 21 maio 2020.

FERNANDES, F. Leituras e legados. São Paulo: Global, 2010.

FERNANDES, F. A natureza sociológica da sociologia. São Paulo: Ática, 1980.

FERNANDES, F. Pensamento e ação: o PT e os rumos do socialismo. São Paulo: Globo, 2006.

FERNANDES, F. Que tipo de República? São Paulo: Brasiliense, 1986.

FERNANDES, F. A revolução burguesa no Brasil: ensaio de interpretação sociológica. São Paulo: Globo, 2005.

FERNANDES, F. Sociedade de classes e subdesenvolvimento. Rio de Janeiro: Zahar, 1968.

FERNANDES, F. A sociologia no Brasil: contribuição para o estudo de sua formação e desenvolvimento. Petrópolis: Vozes, 1977.

FERNANDES, F. A transição prolongada: o período pós-constitucional. São Paulo: Cortez, 1990.

FERNANDES, H. Florestan Fernandes, um sociólogo socialista. Apresentação. In: FERNANDES, H.; FERNANDES JÚNIOR., F. Tudo na vida é sério, mas nada é definitivo. Entrevista com Zilda Iokoi e Marcos Cripa. Revista ADUSP, São Paulo, n. 4, p. $22-27,1995$. LÊNIN, V. Que fazer? São Paulo: Hucitec, 1978.

PAULO NETTO, J. A recuperação marxista da categoria de revolução. In: D’INCAO, M. A. (Org.). O saber militante: ensaios sobre Florestan Fernandes. São Paulo: Unesp, 1987.

PAULO NETTO, J. Ditadura e Serviço Social: uma análise do Serviço Social no Brasil pós-64. São Paulo: Cortez, 2007. 


\section{Notas}

1 Florestan Fernandes constava na primeira lista de cassações do Ato Institucional n. 5 (AI-5), que citava o sociólogo como responsável por atividades subversivas na universidade. O AI-5 foi baixado em 13 de dezembro de 1968, durante o governo do general Costa e Silva. Por meio desse ato, "autorizava o presidente da República, em caráter excepcional e, portanto, sem apreciação judicial, a: decretar o recesso do Congresso Nacional; intervir nos estados e municípios; cassar mandatos parlamentares; suspender, por dez anos, os direitos políticos de qualquer cidadão; decretar o confisco de bens considerados ilícitos; e suspender a garantia do habeas-corpus [...]. No mesmo dia foi decretado o recesso do Congresso Nacional por tempo indeterminado - só em outubro de 1969 o Congresso seria reaberto, para referendar a escolha do general Emílio Garrastazu Médici para a Presidência da República" (D’ARAUJO, [201-?]).

2 Em linhas esquemáticas, a trajetória intelectual e biográfica de Florestan Fernandes esteve diretamente associada à sua inserção nos espaços da universidade. O ingresso na universidade, em sua juventude, foi acompanhado por suas atividades de militância no Partido Socialista Revolucionário (PSR) e pela efervescência dos acontecimentos históricos e políticos e das lutas sociais em plena ditadura do Estado Novo. Contudo, nos anos 1950, Florestan se distanciou da militância político-partidária, tendo se dedicado integralmente à vida acadêmica e à ocupação sucessiva de espaços de notoriedade na estrutura hierárquica da USP. Já entre os anos 1958-1966, participou ativamente da Campanha em Defesa da Escola Pública.

3 Em carta à Barbara Freitag, de 2 de junho de 1969, Florestan expõe essa experiência traumática: “[...] eu e outros professores da USP (e de outras escolas) fomos aposentados compulsoriamente pelo Governo Federal. Trata-se de uma medida que esperava desde 20 de dezembro do ano passado. Os seus resultados nefastos: perda súbita de parte substancial da renda; necessidade de acumular alguns trabalhos remunerados de natureza intelectual; premência de sair do Brasil (pois o artigo $3^{\circ}$ do Ato Institucional no 10 fecha-nos as portas do ensino, da pesquisa e da tecnologia, ao alvitre das autoridades)." (FERNANDES, 1996, p. 146-147).

4 Em 1946, Florestan foi convidado pela Editora Flama de São Paulo para realizar a tradução de Contribuição à crítica da economia política de Marx para a língua portuguesa. A publicação foi acompanhada por uma densa introdução redigida por Florestan, intitulada "Marx e o pensamento sociológico moderno", em que tece uma análise da contribuição de Marx e de Engels para as ciências sociais. Segundo o próprio (FERNANDES, 1977, p. 172-173), seu comprometimento foi "muito mais como sociólogo que como ativista político", mas foi especialmente importante pelo fato de o ter levado à uma determinada "perspectiva" e "prática".

5 Após o período de autocensura mais rígida, os compactos críticos eram uma modalidade de publicação que contribuía para retirar o intelectual crítico do isolamento, ainda que realizasse certa filtragem das críticas (FERNANDES, 2011).

6 Cabe destacar que, já entre 1943 e 1946, por oportunidade de sua militância no Partido Socialista Revolucionário (PSR), Florestan iniciou a colaboração para o jornal Folha da Manhã e para o Estado de São Paulo. Segundo Florestan (1977, p. 162), a colaboração nos jornais só se iniciou “depois de vencer o temor de enfrentar o 'grande público'”. Em outra passagem, o autor considera que “o melhor é que esse tipo de 'repercussão' se refletia no mundo da universidade, abrindo-nos dentro dele as portas fechadas a sete chaves pelos componentes das esferas mais conservadoras de nossas elites culturais" (FERNANDES, 1977, p. 165, grifo do autor). Durante o período em que esteve vinculado ao PSR, Florestan se dedicou à atividade de publicista como parte de suas tarefas militantes junto a jornais trotskistas, dando sua contribuição à imprensa alternativa do circuito de oposição à ditadura do Estado Novo. Também no início de sua trajetória, constam publicações nos jornais Folha da Noite e Jornal de São Paulo. Entre 1950 e 1980, Florestan publicou de forma esporádica em O Estado de São Paulo.

7 No mesmo sentido que o próprio Florestan atribui a Lênin, entendendo que seu lugar de intelectual público advinha de "sua produção teórica e prática como 'publicista'”. (FERNANDES, 1978, p. 14)

8 A quase totalidade desses quinhentos artigos escritos por Florestan para a Folha foi publicada a partir da década de 1980, depois intensificada com a periodicidade semanal (de 26/6/1989 a 7/8/1995). Pouco antes de sua internação hospitalar e já prevendo sua inatividade, Florestan preparou três artigos inéditos, que foram publicados depois de seu falecimento, ocorrido em 10 de agosto de 1995: O rateio da pobreza publicado em 11/8/1995 e Custos sociais do capitalismo e A situação histórica concreta, ambos publicados em 20/8/1995.

9 Nas palavras de seus filhos, Florestan "só se reencontrou novamente, recuperou a felicidade, quando entrou para a política partidária" (FERNANDES; FERNANDES JÚNIOR, 1995, p. 25).

10 Sem medo de ser socialista foi o slogan da campanha em 1990, em diálogo com o Sem medo de ser feliz, da campanha à presidência de Lula no mesmo período.

11 O programa foi ao ar, ao vivo, no dia 5 de dezembro de 1994, quando se aproximava o final do segundo mandato de Florestan. Quando de sua participação no Roda Viva, Florestan já estava com a saúde debilitada. Veio a falecer no ano seguinte, em 10 de agosto de 1995. Sua morte foi decorrente de um malsucedido transplante de fígado, por falha da equipe médica, em virtude da hepatite C, contraída em decorrência de uma transfusão de sangue. 
Keila Lúcio de Carvalho

keilalcarvalho@gmail.com

Doutora em Ciências Humanas pelo Programa de Pós-Graduação em Sociologia e Antropologia (PPGSA)

da Universidade Federal do Rio de Janeiro (UFRJ)

Professora do Centro Federal de Educação Tecnológica Celso Suckow da Fonseca (CEFET-RJ)

\section{CEFET-RJ}

Av. Maracanã, 229 - Maracanã

Rio de Janeiro - RJ - Brasil

CEP: 20271-110

\section{Agradecimentos}

Não se aplica.

Agência financiadora

Não se aplica.

Contribuições das autoras

Não se aplica.

\author{
Aprovação por Comitê de Ética e consentimento para \\ participação \\ Não se aplica. \\ Consentimento para publicação \\ Consentimento da autora. \\ Conflito de interesses \\ Não há conflito de interesses.
}

